\title{
A Review on Biomass For Electricity Generation In Indonesia
}

\author{
D.S. Primadita ${ }^{1}$, I.N.S. Kumara ${ }^{2 *}$, W.G. Ariastina ${ }^{3}$ \\ 1,2,3 Department of Electrical Engineering \\ Faculty of Engineering, Udayana University \\ Bali, Indonesia \\ satya.kumara@unud.ac.id
}

\begin{abstract}
The Indonesian National Energy Policy stipulates that renewable energy must contribute 23\% of total energy consumption by 2025 and increase to $31 \%$ by 2050 . Among many resources of the country, biomass is a renewable energy source whit the potential is estimated at 32,654 MW. This article reviews the biomass and electricity generation implementation in Indonesia to get insights on the development of the biomass for power generation of the country. Currently, the biomass electricity generation technology that has been applied in Indonesia includes direct combustion as fuel for coal power plants or co-firing, converted into refuse-derived fuel, gasification, sanitary landfills, and incinerators. From 2011 to 2019, the installed capacity of biomass power plants reached $1857.5 \mathrm{MW}$ or $33.78 \%$ of the target of $5500 \mathrm{MW}$ in 2025 . The biomass power plants are located in North Sumatra, Jambi, Gorontalo, Riau, West Nusa Tenggara, Papua, Bangka Belitung, North Sulawesi, South Sumatra, East Java, and Jakarta. Considering the high 2025 electricity from biomass target, it is necessary to develop a more intensive biomass power plants because of its large potential, available technology, and its benefits to increase the electrification ratio especially for providing electricity for people in areas not yet covered by the utility network, realizing national energy security, and reducing the use of fossil-based fuels.
\end{abstract}

Index Terms - Bioenergy, biomass, biomass power plants, power generation, gasification

\section{INTRODUCTION}

Indonesia is an archipelago consisting of 17,504 islands divided into 34 provinces' administrative areas [1]. It is a tropical country that is crossed by the equator with an area of 8 million hectares of agriculture and 86 million hectares of forest hence pose an enormous natural potential [2] [3]. Based on data from the Ministry of Energy and Mineral Resources in 2013, the potential for biomass was estimated at 32,654 MW. Biomass resources include palm oil, sugar cane, rubber, coconut, rice, corn, cassava, wood, livestock manure, and municipal waste.

In 2017, Indonesia's electricity system had an installed power capacity of 57,177 MW of which 50,408 MW were generated using conventional power plants and the rest of 6,769 MW were renewable energy power plants [4]. These figures show that Indonesia had only $11.83 \%$ of power plants that use renewable resources. According to the National Energy Policy (KEN), the Government of Indonesia stipulates that in 2025 as much as $23 \%$ of energy should come from renewable energy sources and increase to $31 \%$ by 2050 [5]. In the field of bioenergy, Indonesia has

Corresponding author I.N.S. Kumara - satya.kumara@unud.ac.id utilized $5.1 \%$ of the potential of bioenergy with an installed electric power of 1,671 MW in 2015 [6].

Bioenergy is a term that is widely used to describe gas, liquid, or solid energy products which are mostly derived from biological raw materials namely biomass [7]. Biomass is defined as material derived from living plants, including tree trunks, branches, leaves and residues from agricultural harvesting and processing of seeds or fruits [8]. Biomass is part of solid bioenergy that can be converted into other forms such as gases and liquids through chemical processes.

At present, the use of biomass energy constitutes around $10 \%$ of the world's primary energy production, equivalent to $1,277 \mathrm{Gt}$ of oil or with 53.47 EJ of primary energy consumption of total biomass in 2012 [9]. The contribution of fossil fuels to energy production amounts to more than $80 \%$ of primary energy production. In 2011, $337 \mathrm{TWh}$ of electricity was generated from renewable energy sources and combustible waste [10]. Countries such as the United States (20.6\%), Germany (12.9\%), Brazil (10.1\%), Japan $(6.9 \%)$ and the United Kingdom (4.4\%) are producers of electricity from biomass and the biggest waste is seen from energy production. In terms of electricity production per capita, countries in Northern Europe such as Finland, Sweden, and Denmark have the highest levels of biomass and waste electricity production in the world [11]. 
The utilization of biomass as a source for electric power generation is one solution that can be developed to increase the electrification ratio and realize the national energy security [12]. Biomass is a renewable and sustainable energy source, supplies more biomass than other renewable energy sources such as solar and wind power, and has the potential to supply even more [13]. Biomass is the main energy source of millions of people in the world, but its use decreases when coal, oil, and gas are abundant. The use of biomass to replace fossil fuels can reduce the problem of global carbon dioxide emissions [14].

The results presented here are a review on the development of biomass in Indonesia which covers the potential of biomass resource, types of biomass material in each province, the development of biomass for power generation from the early stage of development until today and the future plan. The review will look at the type of biomass, biomass-to-fuel processing technology, electrical power generation technology, and also the current progress and future plan of the country with respect to biomass power generation. The objective of this study is to obtain the latest status of biomass development in Indonesia and in particular its use in the power generation sector. The results will provide insights and quick reference in understanding the potential, progress, and future development of biomass and its conversion to electricity to date and plans for future development.

\section{II.MATERIAL AND RESEARCH METHODS}

The research uses data sourced from government policies and regulations, scientific publications such as journals and conferences, publications from renewable energy institutions, research and development institutions, industry, and mass media. Government agencies include the Ministry of Energy and Mineral Resources (MEMR), the Ministry of Home Affairs, the Office of Government Secretariate, the agency for technology research and application BPPT, the state-owned utility company PLN, research institute LIPI, and the agency for national planning and development BAPPENAS. The schematic of the study is shown in Figure 1.

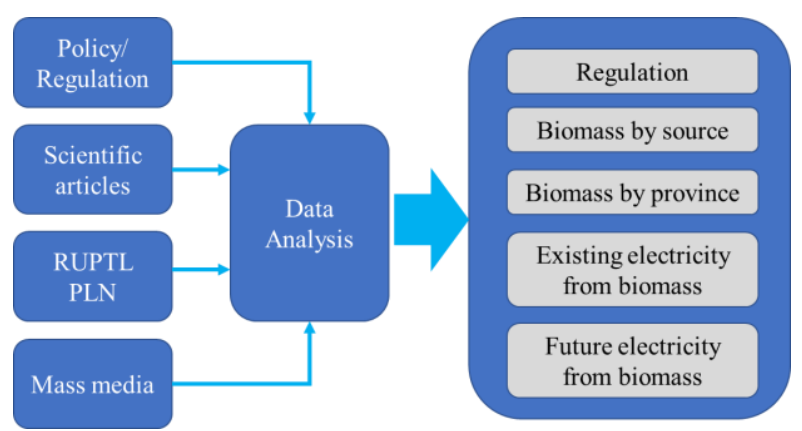

Fig. 1. Schematic of research methodology

\section{RESULT AND DISCUSSION}

\section{A. Indonesian Biomass Policy and Regulations}

The policies and regulations on biomass in Indonesia are in the form of laws, government regulations, presidential instruction, ministerial regulations, regional regulations, and other forms of government regulations. A list of biomass regulations is shown in Table 1.

TABLE I

POLICY AND REGULATION OF BIOMASS IN INDONESIA

\begin{tabular}{|c|c|}
\hline POLICY/REGULATION & CONCERNING \\
\hline UU 30 of 2017 & Energy \\
\hline PP 79 of 2014 & National Energy Policy \\
\hline PERPRES 18 of 2016 & $\begin{array}{l}\text { Accelerating the Development } \\
\text { of Waste Based Power Plants in } \\
\text { DKI Jakarta Province, Tangerang } \\
\text { City, Bandung City, Semarang } \\
\text { City, Surakarta City, Surabaya } \\
\text { City, and Makassar City }\end{array}$ \\
\hline PERPRES 35 of 2018 & $\begin{array}{l}\text { Acceleration of the } \\
\text { Construction of Waste } \\
\text { Processing Installations into } \\
\text { Electrical Energy Based on } \\
\text { Environment-Friendly } \\
\text { Technology }\end{array}$ \\
\hline PERPRES 22 of 2017 & National Energy General Plan \\
\hline INPRES 1 of 2006 & $\begin{array}{l}\text { Provision and Utilization of } \\
\text { Biofuel as Another Fuel }\end{array}$ \\
\hline PERMEN ESDM 21 of 2016 & $\begin{array}{l}\text { Purchasing Electricity from } \\
\text { Biomass Power Plants and } \\
\text { Biogas Power Plants by PT PLN } \\
\text { (Persero) }\end{array}$ \\
\hline PERMEN ESDM 39 of 2017 & $\begin{array}{l}\text { Implementation of Physical } \\
\text { Activity Utilization of New and } \\
\text { Renewable Energy and Energy } \\
\text { Conservation }\end{array}$ \\
\hline PERMEN ESDM 50 of 2017 & $\begin{array}{l}\text { Utilization of Renewable Energy } \\
\text { Sources for the Supply of } \\
\text { Electricity }\end{array}$ \\
\hline PERMEN ESDM 53 of 2018 & $\begin{array}{l}\text { Utilization of Renewable Energy } \\
\text { Sources for the Supply of } \\
\text { Electric Power }\end{array}$ \\
\hline PERGUB BALI 48 of 2019 & Bali Clean Energy \\
\hline PERDA JATENG 3 of 2016 & $\begin{array}{l}\text { Energy Management in Central } \\
\text { Java Province }\end{array}$ \\
\hline
\end{tabular}

From Table 1, it can be seen that policies and regulations governing the use of biomass energy are contained in the law or UU \#30/2017 concerning energy, government regulation PP \#79/2014 concerning national energy policy (KEN), and PERPRES \#22/2017 concerning general plans for national energy (RUEN). Then Perpres \#18/2016 concerning the acceleration of construction of waste-based power plants and PERPRES \#35/2018 
regulates the acceleration of the development of environmentally friendly technology for municipal waste particularly for power generation or PLTSa installations. PLTSa is an abbreviation to describe electric power generation from municipal solid waste.

Ministry of MEMR regulation or Permen ESDM is issued by the ministry to regulate and particularly to accelerate the development of this field. Permen ESDM \#21/2016 concerning the purchase of electricity from PLTBm and PLTBg by the utility which in this case is PLN the state-owned electricity company. PLTBm is an abbreviation to describe power generation using biomass. PLTBg is an abbreviation to describe power generation using biogas. Permen ESDM \#39/2017 concerning the implementation of physical activities of renewable energy utilization and energy conservation, and Permen ESDM $\# 53 / 2018$ concerning the utilization of renewable energy sources for electricity supply. In addition to central government regulation, a number of the provincial government have released their regulations to accelerate the development of this field within their territory. For example, the Government of Bali has released Governor Regulation or Pergub \#48/2019 concerning clean energy development fo Bali. Another example is the Government of Central Java has released Provincial Regulation or PERDA \#3/2016 concerning energy management in Central Java Province.

\section{B. Biomass Potential in Indonesia}

Currently, biomass potential data is available to the public up to the provincial level is available from Directorate of Bioenergy, EBTKE, Ministry of Energy and Mineral Resources. The following table presents the biomass potential of Indonesia by provincial areas.

TABLE II

BIOMASS POTENTIAL BY PROVINCE IN INDONESIA [15]

\begin{tabular}{|c|c|c|c|c|c|c|c|c|c|c|c|}
\hline \multirow{2}{*}{ PROVINCE } & \multicolumn{11}{|c|}{ ELECTRICAL POTENTIAL (MW) } \\
\hline & PALM OIL & $\begin{array}{l}\text { SUGAR } \\
\text { CANE }\end{array}$ & $\begin{array}{c}\text { RUBBER } \\
\text { WOOD }\end{array}$ & COCONUT & $\begin{array}{c}\text { RICE } \\
\text { HUSK }\end{array}$ & CORN & CASSAVA & WOOD & LIVESTOCK & GARBAGE & TOTAL \\
\hline Riau & 2.888 & & 430 & 24 & 88 & 5 & 1 & 962 & 6 & 32 & 4.436 \\
\hline East Java & & 630 & & 11 & 1.476 & 460 & 35 & 4 & 140 & 367 & 3.123 \\
\hline North Sumatera & 1.927 & 30 & 220 & 5 & 472 & 111 & 11 & 4 & 16 & 99 & 2.895 \\
\hline West Java & 22 & 62 & & 6 & 1.772 & 90 & 28 & 4 & 15 & 558 & 2.557 \\
\hline Central Java & & 138 & & 10 & 1.431 & 262 & 39 & 3 & 70 & 278 & 2.231 \\
\hline South Sumatera & 1.187 & 43 & 70 & 3 & 492 & 10 & 4 & 91 & 9 & 62 & 1.971 \\
\hline Jambi & 840 & & 687 & 6 & 96 & 4 & 1 & 148 & 4 & 15 & 1.801 \\
\hline Central Kalimantan & 1.234 & & 140 & 4 & 99 & 1 & 2 & 18 & 2 & 10 & 1.510 \\
\hline \begin{tabular}{|l|} 
Lampung \\
\end{tabular} & 179 & 326 & 114 & 6 & 448 & 217 & 89 & 6 & 27 & 57 & 1.469 \\
\hline West Kalimantan & 758 & & 285 & 4 & 205 & 19 & 3 & 7 & 6 & 23 & 1.310 \\
\hline South Kalimantan & 574 & & 386 & 2 & 281 & 9 & 1 & 13 & 5 & 19 & 1.290 \\
\hline Aceh & 646 & & 233 & 3 & 240 & 13 & 1 & & 17 & 21 & 1.174 \\
\hline East Kalimantan & 837 & & 43 & 1 & 58 & 2 & 1 & 5 & 3 & 15 & 965 \\
\hline South Sulawesi & 25 & 22 & & 5 & 696 & 119 & 7 & 18 & 36 & 33 & 961 \\
\hline West Sumatera & 485 & & 55 & 5 & 337 & 36 & 2 & 1 & 12 & 23 & 956 \\
\hline Bengkulu & 434 & & 108 & & 79 & 11 & 1 & & 4 & 8 & 645 \\
\hline Banten & 41 & & & 3 & 297 & 3 & 1 & & 2 & 117 & 464 \\
\hline West Nusa Tenggara & & & & 3 & 315 & 31 & 1 & 1 & 25 & 28 & 404 \\
\hline Central Sulawesi & 117 & & & 11 & 158 & 18 & 1 & 1 & 8 & 11 & 325 \\
\hline Madura & & & & 3 & 120 & 90 & 5 & & 32 & 31 & 281 \\
\hline East Nusa Tenggara & & & & 3 & 90 & 64 & 17 & 18 & 28 & 20 & 240 \\
\hline Yogyakarta & & 15 & & 3 & 126 & 30 & 9 & & 14 & 27 & 224 \\
\hline Bangka Belitung & 214 & & & & 3 & & & & & 5 & 222 \\
\hline West Sulawesi & 134 & & & 2 & 56 & 5 & 1 & & 3 & 5 & 206 \\
\hline Bali & & & & 4 & 131 & 10 & 1 & & 23 & 22 & 191 \\
\hline North Sulawesi & & & & 15 & 88 & 45 & 1 & & 4 & 10 & 163 \\
\hline Southeast Sulawesi & 47 & & & 2 & 69 & 11 & 3 & 1 & 8 & 10 & 151 \\
\hline Gorontalo & & 20 & & 3 & 42 & 54 & & & 7 & 4 & 130 \\
\hline DKI Jakarta & & & & & 1 & & & & & 126 & 127 \\
\hline North Kalimantan & 118 & & & & & & & & & & 118 \\
\hline Papua & 42 & & & 13 & 16 & 1 & 1 & 9 & 2 & 12 & 96 \\
\hline West Papua & 33 & & & 1 & 4 & & & 12 & 3 & 2 & 55 \\
\hline North Maluku & & & & 14 & 9 & 2 & 1 & 1 & 2 & 5 & 34 \\
\hline Maluku & & & & 4 & 13 & 2 & 1 & 3 & 3 & 7 & 33 \\
\hline Riau Islands & 10 & & & 1 & & & & & 1 & 3 & 15 \\
\hline TOTAL & 12.792 & 1.286 & 2.771 & 180 & 9.808 & 1.735 & 269 & 1.330 & 537 & 2.065 & 32.773 \\
\hline
\end{tabular}


Based on Table 2, it can be seen there are ten types of biomass sources that can be utilized as an energy source. The source is palm oil, sugar cane, rubber, coconut, rice, corn, cassava, wood, livestock, and urban waste. Parts of palm oil that can be utilized are the meat and its kernel. These can be converted to biodiesel oil. Then coir and the shells can be used as fuel as co-firing in a coal power plant or PLTU. PLTU is an abbreviation to describe a coal power plant. Sugarcane bagasse can also be used as fuel for

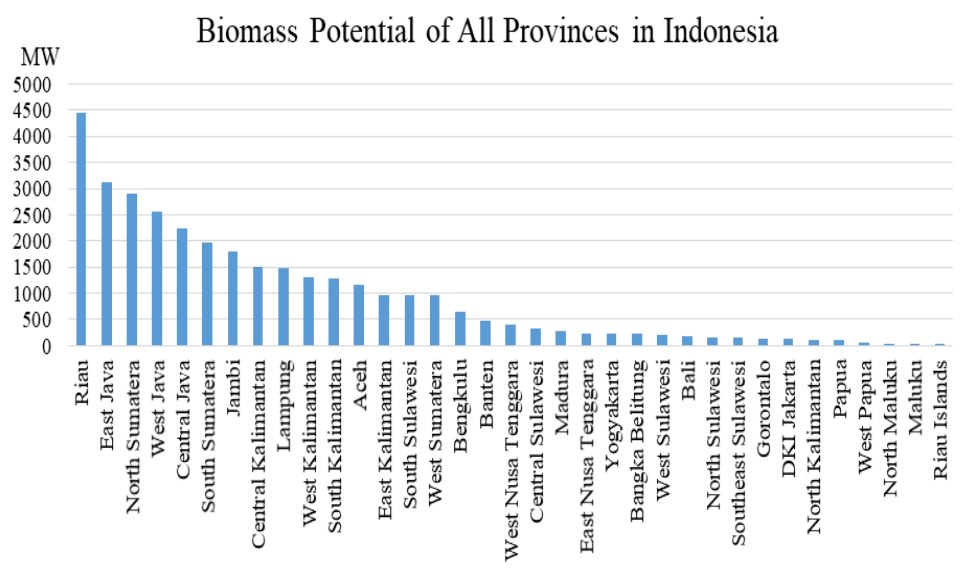

(a) Biomass potential by province electricity generation. Then the rubber tree, the trunk that is no longer producing rubber latex is used as fuel for power plants. Then the shell and coconut fiber can also be used as fuel for electricity generation. Rice husk after harvest can also be used as fuel for power plants. Corn cobs after harvest can also be used as fuel for power plants. Cassava stems can also be used as fuel for power plants. Any type of wood can also be used as fuel for power plants. Livestock manure and urban waste can also be used as biofuels.

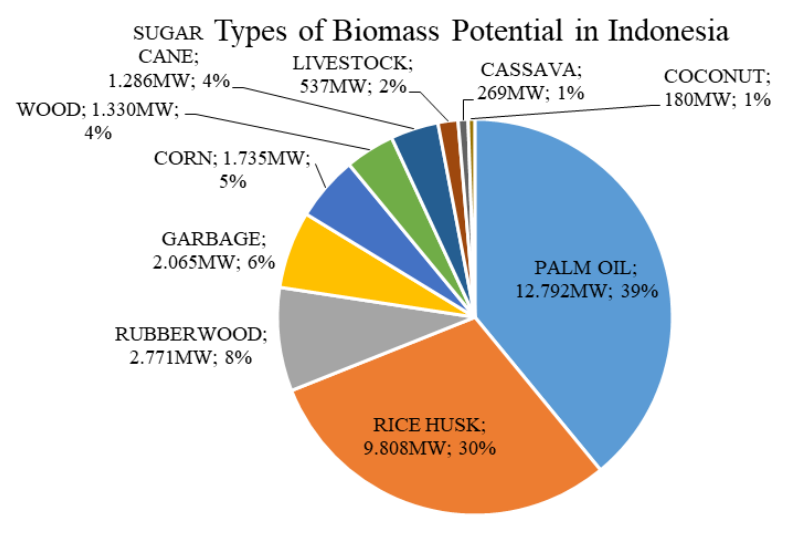

(b) Types of potential biomass in Indonesia

plants at $12 \mathrm{GW}$. Then there are also other sources of raw materials such as sugar cane, rubber, coconut, rice, corn, cassava, wood, livestock, and municipal waste.

\section{Biomass Power Plant}

The plan to develop a biomass power plant is contained in the presidential regulation number 22 of 2017 concerning the national energy policy. The capacity of biomass power plants has been recorded in the Ministry of Energy and Mineral Resources from 2014 to the end of 2018. The following is the biomass power generation capacity from 2014 to 2019 which shows targets and realization every year. 


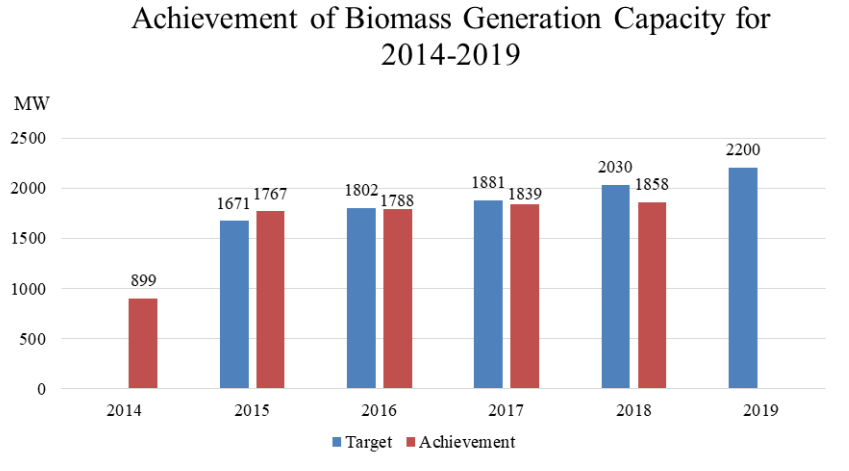

(a) Achievement of biomass generation capacity for 2014-2019

Fig. 3. Biomass generation in 2014-2019 and plans for 2020-2025

In the development of biomass power plants in the last 5 years, it can be seen that in 2014 the installed capacity of PLTBm reached 898.5 MW. Then it is targeted to have $1672 \mathrm{MW}$ in 2015 but the achievement can exceed the target of $1767.1 \mathrm{MW}$ or $94.57 \%$ of the target. In 2016 it is targeted that PLTBm has an installed capacity of 1801.6 MW, but the achievement is only $1787.9 \mathrm{MW}$ or $0.76 \%$ exceeding the target. In 2017 the installed capacity reached 1857.5 MW of the target of $2030 \mathrm{MW}$ or reached $84.43 \%$ of the target. Then in 2019, it is targeted that PLTBm in Indonesia has $2200 \mathrm{MW}$ of installed capacity, while in the media or new news there are $5.7 \mathrm{MW}$ of new plants installed in 2019. The national energy policy also has a bioenergy utilization plan until 2025 as shown in Figure 3.

Until 2025 the Indonesian government targets to have $5500 \mathrm{MW}$ of installed capacity from the use of Biomass, which is 2018 only has $1857.5 \mathrm{MW}$ installed. This means that the government must catch up to $3643 \mathrm{MW}$ in the next 6 years.

\section{Development of Biomass Power Plant}

The development of power plants that use biomass fuels on a large scale and was first recorded was in 2010. The first development began in the field of industrial fields, starting from Medan Industrial Zone (KIM) I and (KIM) II, then (KIM) III in the year 2013. Following is a table of biomass developments in Indonesia from 2010 to 2019 based on data from the Ministry of Energy and Mineral Resources, the news media, and the PLN RUPTL.

Processing biomass into electrical energy in Indonesia has implemented 3 types of technologies, namely, sanitary landfill, gasification, and combustion. Sanitary landfill technology converts solid biomass into biofuel by removing and stacking biomass in concave locations to be compacted and stockpiled with soil so that the decomposition results can later produce biofuels in the form of gases and liquids. Biofuel can be used as fuel for PLTD / PLTG Gasification technology is the processing of biomass into syngas by using a gasifier reactor to go through 4 stages of the process of drying, decomposition, oxidation, and reduction. Syngas

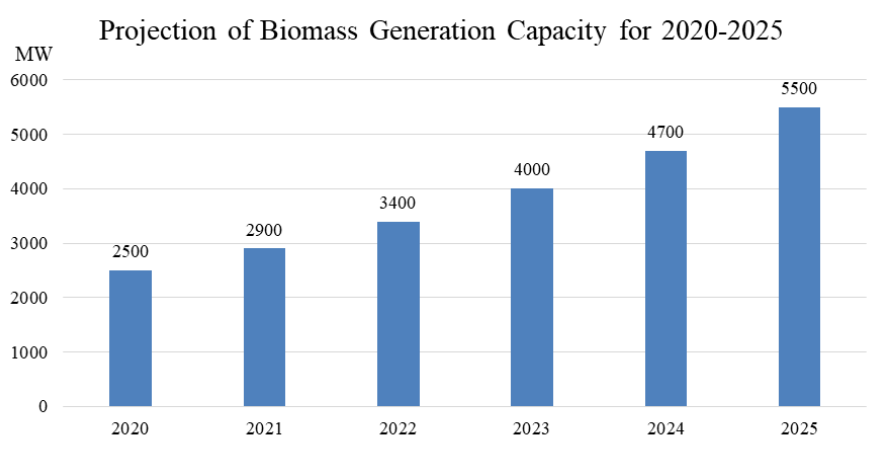

(b) Projection of biomass generation capacity for 2020-2025

produced can be used as fuel for PLTD / PLTG Combustion technology is a technology that utilizes heat from the combustion of biomass, both directly and mixed with coal. The heat generated in the combustion process can be used to heat the boiler at the power plant to produce steam which will move the steam turbine. The RDF technology or Refused Derived Fuel, which is the technology that converts biomass into small solids for fuel which is commonly called pellets or briquettes so that it can later be used as raw material for gasification and combustion.

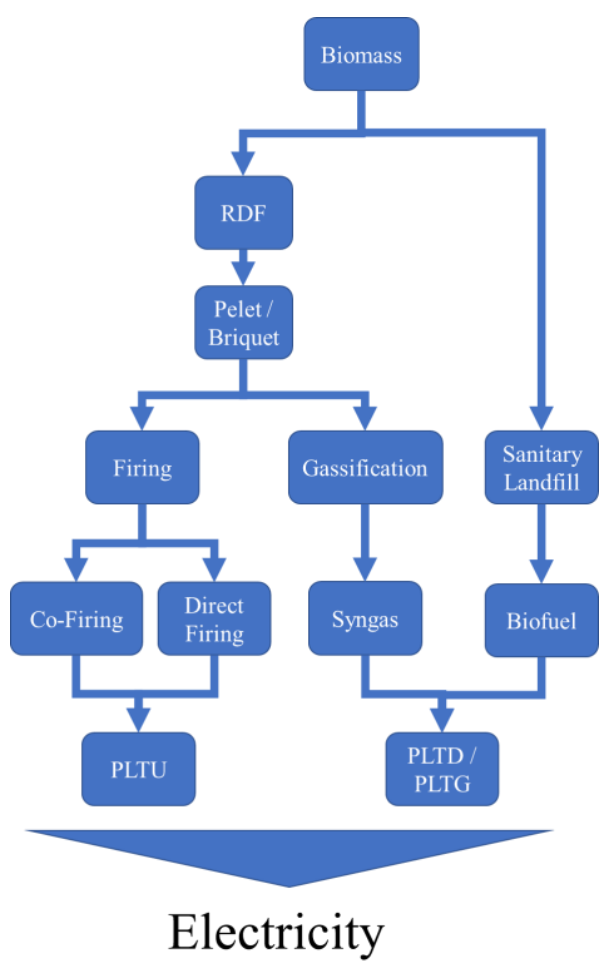

Fig. 4. Biomass Processing Technology in Indonesia 
TABLE III

DEVELOPMENT OF BIOMASS IN INDONESIA FROM 2011-2019

\begin{tabular}{|c|c|c|c|c|c|c|c|}
\hline NAME & LOCATION & YEAR & RESOURCES & TECHNOLOGY & CAPACITY & MANAGEMENT & STATUS \\
\hline $\begin{array}{l}\text { PLTBm North } \\
\text { Sumatera }\end{array}$ & $\begin{array}{l}\text { Industrial Area Medan I, Medan } \\
\text { Deli, North Sumatra }\end{array}$ & 2010 & $\begin{array}{l}\text { Palm shells, sugar cane, rice husks, } \\
\text { corncobs, tapioca dregs up to sawdust }\end{array}$ & Firing & $30 \mathrm{MW}$ & PT. Growth Sumatra Industry & $\begin{array}{l}\text { Operating excess } 15 \\
\text { MW }\end{array}$ \\
\hline PLTBm Riau & Perawang, Minas, Riau & 2010 & Palm Waste & Firing & $3 \mathrm{MW}$ & PT. Indah Kiat Pulp and Paper & Operating \\
\hline $\begin{array}{l}\text { PLTBm West } \\
\text { Kalimantan }\end{array}$ & $\begin{array}{l}\text { Kubu Raya, Pontianak, West } \\
\text { Kalimantan }\end{array}$ & 2011 & Plywood Waste & Firing & $7,5 \mathrm{MW}$ & PT Harjohn Timber & Operating \\
\hline $\begin{array}{l}\text { PLTBm North } \\
\text { Sumatera }\end{array}$ & $\begin{array}{l}\text { Industrial Area Medan II, Deli } \\
\text { Serdang, North Sumatra }\end{array}$ & 2012 & $\begin{array}{l}\text { Palm shells, sugar cane, rice husks, } \\
\text { corncobs, tapioca dregs up to sawdust }\end{array}$ & Firing & $25 \mathrm{MW}$ & PT. Growth Sumatra & $\begin{array}{l}\text { Operating excess } 20 \\
\text { MW }\end{array}$ \\
\hline $\begin{array}{l}\text { PLTBm North } \\
\text { Sumatera }\end{array}$ & $\begin{array}{l}\text { Industrial Area Medan III, } \\
\text { Tangkahan, North Sumatra }\end{array}$ & 2013 & $\begin{array}{l}\text { Palm shells, sugar cane, rice husks, } \\
\text { corncobs, tapioca dregs up to sawdust }\end{array}$ & Firing & $30 \mathrm{MW}$ & PT. Growth Asia & $\begin{array}{l}\text { Operating excess } 20 \\
\text { MW }\end{array}$ \\
\hline PLTBm Jambi & $\begin{array}{l}\text { Payaselincah, East Jambi, Jambi } \\
\text { City }\end{array}$ & 2013 & Palm Shells & Firing & $30 \mathrm{MW}$ & $\begin{array}{l}\text { PT Rimba Palma Sejahtera } \\
\text { Lestari }\end{array}$ & Already On Grid \\
\hline PLTBm Banten & Cilegon, Banten & 2013 & $\begin{array}{l}\text { Palm shells, sugar cane, rice husks, } \\
\text { corncobs, tapioca dregs up to sawdust }\end{array}$ & Firing & $30 \mathrm{MW}$ & PT Indocoke & Without explanation \\
\hline $\begin{array}{l}\text { PLTBm North } \\
\text { Sumatera }\end{array}$ & Simalunggun, North Sumatera & 2013 & $\begin{array}{l}\text { Palm shells, sugar cane, rice husks, } \\
\text { corncobs, tapioca dregs up to sawdust }\end{array}$ & Firing & $30 \mathrm{MW}$ & PT Harkat Sejahtera & Operating \\
\hline $\begin{array}{l}\text { PLTBm West } \\
\text { Kalimantan }\end{array}$ & Ketapang, West Kalimantan & 2013 & Plywood Waste & Firing & $7 \mathrm{MW}$ & PT Suka Jaya Makmur & Development \\
\hline PLTBm Gorontalo & Pulubala, Gorontalo & 2014 & Corncob & Gassification & $500 \mathrm{KW}$ & Kementrian BUMN dan PLN & Operating \\
\hline PLTBm Riau & Bantan, Bengkalis, Riau & 2015 & Palm Waste & Firing & $10 \mathrm{MW}$ & PT Meskom Agro Sarimas & Operating \\
\hline $\begin{array}{l}\text { PLTBm North } \\
\text { Sumatera }\end{array}$ & $\begin{array}{l}\text { Industrial Area Medan I, Medan } \\
\text { Deli, North Sumatera }\end{array}$ & 2015 & Palm Waste & Firing & $3 \mathrm{MW}$ & PT Victorindo & Operating \\
\hline $\begin{array}{l}\text { PLTBm North } \\
\text { Sumatera }\end{array}$ & Medan, North Sumatera & 2015 & Palm Waste & Firing & $1,8 \mathrm{MW}$ & PT Perkebunan Nusantara III & Operating \\
\hline PLTBm Riau & $\begin{array}{l}\text { Kepenuhan, Rokan Hulu } \\
\text { Regency, Riau }\end{array}$ & 2015 & Palm oil mill waste & Firing & $25 \mathrm{MW}$ & PT Riau Prima energi & $\begin{array}{l}\text { Operating 10MW and } \\
\text { Added 15MW in } 2016\end{array}$ \\
\hline $\begin{array}{l}\text { PLTBm East } \\
\text { Kalimantan }\end{array}$ & $\begin{array}{l}\text { Mook Manaar Bulath, West } \\
\text { Kutai, East Kalimantan }\end{array}$ & 2016 & Wood Pellet & Firing & $20 \mathrm{MW}$ & PT Sekawan Intipratama Tbk & Without explanation \\
\hline PLTBm East Java & Gedeg, Mojokerto, East Java & 2016 & Sugar Cane & Firing & $2 \mathrm{MW}$ & PT Perkebunan Nusantara X & Without explanation \\
\hline PLTBm NTT & $\begin{array}{l}\text { Bodo Hula, Lamboya, West } \\
\text { Sumba, NTT }\end{array}$ & 2016 & Kaliandra Wood & Gassification & $1 \mathrm{MW}$ & PT Pasadena Engineering & Operating since 2017 \\
\hline PLTBm Papua & Wapeko, Merauke, Papua & 2017 & $\begin{array}{l}\text { Forest products, in the form of various } \\
\text { types of wood, such as acacia, Elucalyptus } \\
\text { wood, Meulaluca wood }\end{array}$ & Firing & $3,5 \mathrm{MW}$ & PT Merauke Narada Energi & Without explanation \\
\hline PLTBm Riau Islands & Tanjung Batu, Riau Islands & 2017 & Palm Waste & Firing & $1 \mathrm{MW}$ & Tanjung Batu & Without explanation \\
\hline PLTBm Riau & Tembilahan, Riau & 2017 & Coconut & Firing & $5 \mathrm{MW}$ & PT Inhil Sarimas Kelapa & Operating \\
\hline $\begin{array}{l}\text { PLTBm Bangka } \\
\text { Belitung }\end{array}$ & Bangka Belitung & 2017 & Palm Shells & Firing & $18 \mathrm{MW}$ & Kencana Agri Ltd & $\begin{array}{l}7 \text { - } 5 \text { MW Operating and } \\
6 \text { MW Was Built }\end{array}$ \\
\hline PLTBm Lampung & $\begin{array}{l}\text { Teluk betung, Bandar Lampung } \\
\text { City, Lampung }\end{array}$ & 2017 & Sugar Cane & Firing & $5 \mathrm{MW}$ & PT Gunung Madu Plantation & Operating \\
\hline $\begin{array}{l}\text { PLTBm North } \\
\text { Sulawesi }\end{array}$ & $\begin{array}{l}\text { Bailang, Manado, North } \\
\text { Sulawesi }\end{array}$ & 2018 & $\begin{array}{l}\text { Fermentation of cow dung with organic } \\
\text { waste }\end{array}$ & Firing & $45 \mathrm{KW}$ & $\begin{array}{l}\text { Pemkot Manado, Universitas } \\
\text { Sam Ratulangi, Manado and } \\
\text { Universitas Feng Chia Taiwan }\end{array}$ & Development \\
\hline $\begin{array}{l}\text { PLTBm West } \\
\text { Kalimantan }\end{array}$ & $\begin{array}{l}\text { Wajok Hulu Village, Siantan, } \\
\text { Mempawah Regency, West } \\
\text { Kalimantan Province }\end{array}$ & 2018 & $\begin{array}{l}\text { The remaining agricultural produce, oil } \\
\text { palm shells, empty fruit bunches, coconut } \\
\text { fibers, and other agricultural wastes }\end{array}$ & Firing & $15 \mathrm{MW}$ & PT Rezeki Perkasa Sejahtera & $\begin{array}{l}\text { Operating since } 23 \text { April } \\
2018\end{array}$ \\
\hline $\begin{array}{l}\text { PLTBm Bangka } \\
\text { Belitung }\end{array}$ & West Bangka, Bangka Belitung & 2018 & Palm Waste & Firing & $6 \mathrm{MW}$ & PT Energi Karya Persada & Without explanation \\
\hline $\begin{array}{l}\text { PLTBm Bangka } \\
\text { Belitung }\end{array}$ & $\begin{array}{l}\text { Mempaya Village, Damar, East } \\
\text { Belitung, Bangka Belitung }\end{array}$ & 2018 & $\begin{array}{l}\text { Wood processed into wood chips, Palm } \\
\text { Shells, Palm Fiber }\end{array}$ & Firing & 7,5 MW & $\begin{array}{l}\text { PT Bangka Biogas Sinergy, } \\
\text { Belitung Energy, and Listrindo } \\
\text { Kencana }\end{array}$ & Can Only Supply 3-4MW \\
\hline $\begin{array}{l}\text { PLTBm South } \\
\text { Sumatera }\end{array}$ & $\begin{array}{l}\text { Ogan Ilir Regency, South } \\
\text { Sumatra }\end{array}$ & 2019 & Rice Husk & Firing & $3 \mathrm{MW}$ & PT Buyung Poetra Sembada & $\begin{array}{l}\text { Targeted to operate on } \\
\text { quartal III/2019 }\end{array}$ \\
\hline PLTSa East Java & TPA Benowo, Surabaya & 2019 & Municipal Solid Waste & $\begin{array}{l}\text { Gassification \& } \\
\text { Sanitary Landfill }\end{array}$ & $\begin{array}{c}2 \mathrm{MW}+9 \\
\mathrm{MW}\end{array}$ & PT Sumber Organik & $\begin{array}{l}\text { Operating } 2 \text { MW from } \\
\text { landfill gas and was built } \\
9 \text { MW Gassification }\end{array}$ \\
\hline PLTSa Bali & Lepang, Klungkung, Bali & 2019 & Municipal Solid Waste & Gassification & $\begin{array}{c}20 \mathrm{KW}+40 \\
\mathrm{KW}\end{array}$ & $\begin{array}{l}\text { PT Indonesia Power, STT PLN, } \\
\text { and Pemkab Klungkung }\end{array}$ & $\begin{array}{l}\text { Operating } 10 \mathrm{KW} \text { in } \\
\text { Lepang and } 40 \mathrm{KW} \text { in } \\
\text { Pesanggaran unit }\end{array}$ \\
\hline PLTSa Jakarta & TPA Bantargebang, Jakarta & 2019 & Municipal Solid Waste & Firing & $700 \mathrm{KW}$ & $\begin{array}{l}\text { Menkomaritim, Menristek dan } \\
\text { BPPT }\end{array}$ & Officialy Operated \\
\hline
\end{tabular}


Based on the biomass development table from 2010 to 2019, it can be seen that the PLTBm North Sumatera in the Industrial area is the first and largest PLTBm in Indonesia. North Sumatera PLTBm uses raw materials of palm shells, sugar cane, rice husks, corncobs, tapioca flour dregs, to wood dust with direct combustion technology for PLTU fuel. This power plant has a capacity of $30 \mathrm{MW}$ and operates $15 \mathrm{MW}$ for electricity needs in the industrial area then the excess power plant will be distributed to the PLN network.

The most widely used biomass is oil palm shells which are used as fuel for PLTU. The first power plant using gasification technology was in the PLTBm Gorontalo, with a capacity of $500 \mathrm{KW}$. In addition to oil palm shells, there are also fuels such as sugar cane, rice husk, corn cobs, flour pulp, wood powder, calliandra wood, acacia wood, eucalyptus wood, melaleuca wood, empty fruit bunches, coconut fibers, agricultural waste, livestock waste, woodchip oil palm fiber, and municipal waste. Then the plants that use municipal solid waste as raw material are classified as PLTSa or garbage power plants.

Based on Figure 5, it can be seen that the largest biomass generator is in PLTBm North Sumatra and the smallest is in PLTBm North Sulawesi.PLTBm North Sumatra Province is the largest because it is managed by the Growth Steel Group which is a multinational company and also this PLTBm has been in existence since 2010. The purpose of the construction of the Medan PLTBm is to supply the electrical energy needs of factories in Medan Industrial Estate and excess electricity production will be sold to PLN. Then the PLTBm North Sulawesi became the smallest PLTBm because it was still under development by the Manado City Government in collaboration with Sam Ratulangi University, and Taiwan's Feng Chia University.

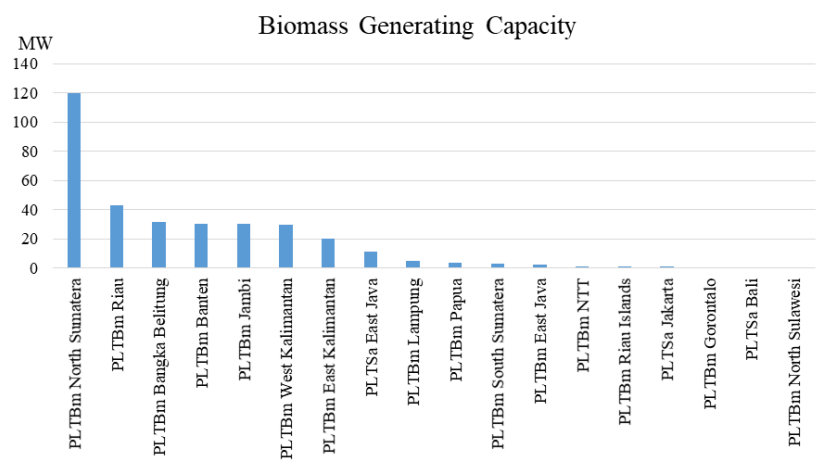

Fig. 5. Biomass Generating Capacity

\section{E. Future Plan for Biomass Power Generation}

After 2019, there are several plants planned to be built. The following is a table of the development of biomassfueled power plants after 2019 based on ESDM data, news media, and PLN RUPTL.

TABLE IV

BIOMASS FOR POWER GENERATION PLAN OF INDONESIA

\begin{tabular}{|c|c|c|c|c|c|c|c|}
\hline NAME & LOCATION & YEAR & RESOURCES & TECHNOLOGY & CAPACITY & MANAGEMENT & STATUS \\
\hline $\begin{array}{l}\text { PLTBm North } \\
\text { Sumatera }\end{array}$ & $\begin{array}{l}\text { Tanjung Selamat, Deli Serdang, } \\
\text { North Sumatera }\end{array}$ & 2020 & Rubberwood & Firing & 9,9 MW & $\begin{array}{l}\text { PT Cipta Multi Listrik } \\
\text { Nasional }\end{array}$ & Reached the PPA Agreement Phase \\
\hline $\begin{array}{l}\text { PLTSa West } \\
\text { Java }\end{array}$ & Bekasi, West Java & 2021 & Municipal Solid Waste & RDF & $9 \mathrm{MW}$ & PT Nusa Wijaya Abadi & $\begin{array}{l}\text { Not yet in operation and damage } \\
\text { has occurred during the trial }\end{array}$ \\
\hline $\begin{array}{l}\text { PLTSa Central } \\
\text { Java }\end{array}$ & $\begin{array}{l}\text { TPA Putri Cempo, Mojosongo, } \\
\text { Solo, Central Java }\end{array}$ & 2021 & Municipal Solid Waste & Gassification & $10 \mathrm{MW}$ & $\begin{array}{l}\text { PT Solo Citra Metro } \\
\text { Plasma Power }\end{array}$ & $\begin{array}{l}\text { Planned and already the signature } \\
\text { stage of PPA or PJBTL }\end{array}$ \\
\hline PLTSa Bali & TPA Suwung, Denpasar, Bali & 2021 & Municipal Solid Waste & Sanitary Landfill & $20 \mathrm{MW}$ & $\begin{array}{l}\text { PT Indonesia Power and } \\
\text { PT Waskita Karya }\end{array}$ & $\begin{array}{l}\text { Planned and at the feasibility study } \\
\text { stage }\end{array}$ \\
\hline $\begin{array}{l}\text { PLTSa } \\
\text { Palembang }\end{array}$ & $\begin{array}{l}\text { TPA Karya Jaya, Palembang, } \\
\text { South Sumatera }\end{array}$ & 2021 & Municipal Solid Waste & Incenerator or Firing & $20 \mathrm{MW}$ & PT Indo Green Power & Planned \\
\hline PLTSa Jakarta & $\begin{array}{l}\text { TPA Sunter, North Jakarta, DKI } \\
\text { Jakarta }\end{array}$ & 2022 & Municipal Solid Waste & & $\begin{array}{l}35 \mathrm{MW}+3 \\
\mathrm{MW}\end{array}$ & PT Jakpro dan Fortum & $\begin{array}{l}\text { Planned and waiting for KLHK } \\
\text { sweets }\end{array}$ \\
\hline $\begin{array}{l}\text { PLTSa West } \\
\text { Java }\end{array}$ & $\begin{array}{l}\text { TPA Gedebage, East Bandung, } \\
\text { West Java }\end{array}$ & 2022 & Municipal Solid Waste & Direct Firing & $29 \mathrm{MW}$ & $\begin{array}{l}\text { PT. Bandung Raya Indah } \\
\text { Lestari }\end{array}$ & $\begin{array}{l}\text { Planned and there is already a } \\
\text { capacity of } 7 \mathrm{MW}\end{array}$ \\
\hline PLTSa Banten & $\begin{array}{l}\text { TPA Rawa Kucing, Neglasari, } \\
\text { Tangerang, Banten }\end{array}$ & 2022 & Municipal Solid Waste & & $20 \mathrm{MW}$ & $\begin{array}{l}\text { PT. Tangerang Nusa } \\
\text { Global }\end{array}$ & Planned \\
\hline $\begin{array}{l}\text { PLTSa Central } \\
\text { Java }\end{array}$ & $\begin{array}{l}\text { TPA Jatibarang, Semarang, } \\
\text { Central Java }\end{array}$ & 2022 & Municipal Solid Waste & $\begin{array}{l}\text { Incenerator and Landfill } \\
\text { Gas }\end{array}$ & $20 \mathrm{MW}$ & Pemkot and Denmark & $\begin{array}{l}\text { Planned and already in operation } \\
1.3 \mathrm{MW} \text { by } 2019\end{array}$ \\
\hline $\begin{array}{l}\text { PLTSa South } \\
\text { Sulawesi }\end{array}$ & $\begin{array}{l}\text { TPA Antang, Makassar, South } \\
\text { Sulawesi }\end{array}$ & 2022 & Municipal Solid Waste & & $20 \mathrm{MW}$ & Pemkot Makassar & Planned \\
\hline PLTSa Banten & $\begin{array}{l}\text { TPA Cipeucang, South } \\
\text { Tanggerang, Banten }\end{array}$ & 2022 & Municipal Solid Waste & & $20 \mathrm{MW}$ & & Planned \\
\hline $\begin{array}{l}\text { PLTSa North } \\
\text { Sulawesi }\end{array}$ & Manado, North Sulawesi & 2022 & Municipal Solid Waste & & $20 \mathrm{MW}$ & & Planned \\
\hline $\begin{array}{l}\text { PLTBm North } \\
\text { Sumatera }\end{array}$ & Kepulauan Nias, North Sumatra & & Bamboo & & $18 \mathrm{MW}$ & PT Energi Infranusantara & Planned \\
\hline $\begin{array}{l}\text { PLTBm West } \\
\text { Sumatera }\end{array}$ & Mentawai, West Sumatra & & Bamboo & & $5 \mathrm{MW}$ & & \\
\hline $\begin{array}{l}\text { PLTBm West } \\
\text { Kalimantan } \\
\end{array}$ & Sintang, West Kalimantan & & Palm Shells & & $10 \mathrm{MW}$ & & \\
\hline $\begin{array}{l}\text { PLTBm North } \\
\text { Maluku }\end{array}$ & North Maluku & & Forest Products & & $10 \mathrm{MW}$ & $\begin{array}{l}\text { PT Energi Bersih } \\
\text { Halmahera }\end{array}$ & \\
\hline
\end{tabular}


Based on the biomass generator data table that will be built after 2019, there will be 12 power plants that will be built from 2020 to 2022. Then there will be 11 PLTSa that will be built in the future to overcome the waste problem in

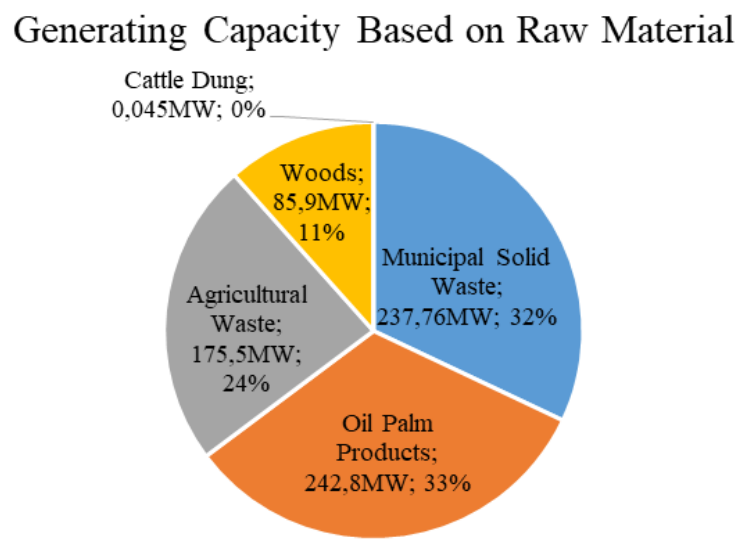

(a) Generating capacity based on raw materials

Fig. 6. Biomass generation in Indonesia

In figure 6 it can be seen that $33 \%$ of biomass power generation capacity uses palm oil products fuel using, $32 \%$ of municipal solid waste, $24 \%$ of agricultural waste, $11 \%$ uses woody timber, and livestock filth is still below $0 \%$ of all generating capacity. Palm products here include oil palm shells and palm fiber. Timber here includes calliandra, acacia, eucalyptus, melaleuca, sawdust, wood chips, and bamboo. Then the agricultural waste here includes rice husks, sugar cane, corncobs, tapioca flour, and empty fruit bunches. Oil Palm Products dominates biomass generation capacity because palm oil production is very high in Indonesia.

The technology used there is that uses direct combustion as PLTU fuel, this technology can also be called direct firing which consists of biomass firing and co-firing. It is said firing if the PLTU only uses biomass fuel only and it is said co-firing when using coal as a fuel mixture. Then it is converted into refuse-derived fuel (RDF) or waste derived from waste, which is a fuel made from municipal solid waste (MSW) or municipal waste using briquetting or pelletization techniques. Gasification technology is the process of converting solid fuels to gas or syngas fuels for electricity generation fuels. Sanitary landfill is the process of decaying garbage in the soil to take gas and liquid as fuel. Then incinerators that use direct combustion technology or firing, usually applied to MSW or municipal waste, heat from combustion is used to heat the boiler and produce steam to drive the steam turbine. The percentage of generating capacity based on technology can be seen in Figure 6.

In Figure 6 it can be seen that $82 \%$ of biomass generating capacity uses direct combustion technology, $11 \%$ sanitary various cities. In addition to municipal waste, there is also PLTBm that uses rubberwood fuel, bamboo, and forest products. Based on the type of biomass, the fuel of the generator can be presented as shown in Figure 6 .

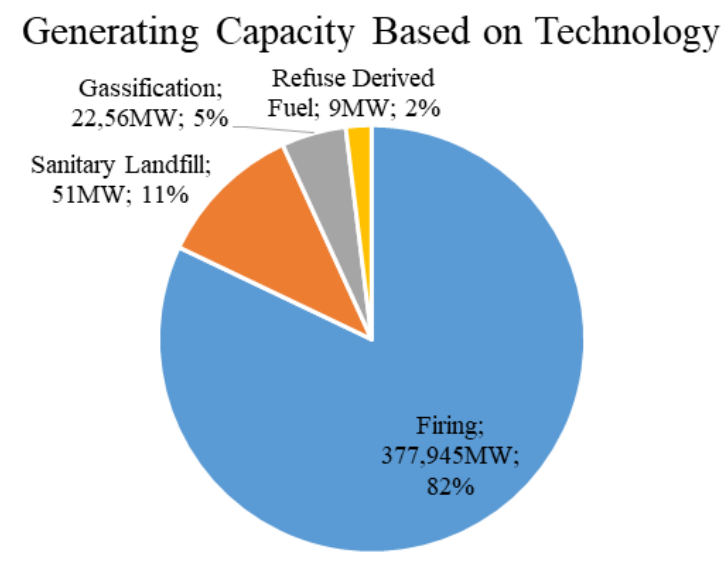

(b) Generating capacity based on technology

landfill, 5\% gasification, and $2 \%$ is converted to RDF. This happens because direct combustion is the easiest and cheapest way to utilize biomass, besides those generators that use this technology also have large generating capacity.

\section{CONCLUSION}

This article has reviewed the development of biomass potential and biomass electricity generation in Indonesia. Indonesia is rich in biomass with potential is estimated at $32,773 \mathrm{MW}$. The source or form of biomass is sugar cane, rubber, coconut, rice, corn, cassava, wood, livestock, and municipal waste.

A number of technologies have been used in the power generation of biomass-fueled electricity such as direct combustion as coal power plant's fuel, converted to refusederived fuel, gasification, sanitary landfills, and incinerators. Currently, the largest implementation of biomass for power generation is in municipal waste management through co-firing technology.

There is little information regarding biomass for power generation prior to 2011. From 2011 to 2019, the installed capacity of biomass for power generation was $1857.5 \mathrm{MW}$ which is around $33.78 \%$ of the 2025 target. In the future, it is necessary to intensify the implementation of biomass for electricity programs both for remote and urban areas as a clean and sustainable source of electrical energy.

\section{NOMENCLATURE}

Bappenas National Development Planning Agency BPPT Agency for Assessment and Application of Technology 


$\begin{array}{ll}\text { EBTKE } & \text { Renewable Energy and Energy Conservation } \\ \text { EJ } & \text { Exajoule } \\ \text { ESDM } & \text { Energy and Mineral Resources } \\ \text { Gt } & \text { Giga Tone } \\ \text { GW } & \text { GigaWatt } \\ \text { INPRES } & \text { Presidential Instructions } \\ \text { KEN } & \text { National Energy Policy } \\ \text { KIM } & \text { Medan Industrial Zone } \\ \text { KLHK } & \text { Ministry of Environment and Forestry } \\ \text { KW } & \text { KiloWatt } \\ \text { LIPI } & \text { Indonesian Institute of Sciences } \\ \text { MSW } & \text { Municipal Solid Waste } \\ \text { MW } & \text { MegaWatt } \\ \text { PERDA } & \text { Local Regulation } \\ \text { PERGUB } & \text { Governor's Regulation } \\ \text { PERPRES } & \text { Presidential Decree } \\ \text { PERMEN } & \text { Ministerial Regulation } \\ \text { PJBTL } & \text { Power Purchasing Agreement } \\ \text { PLN } & \text { National Electricity Company } \\ \text { PLTBm } & \text { Biomass Power Plant } \\ \text { PLTBg } & \text { Biogas Power Plant } \\ \text { PLTSa } & \text { Garbage power plant } \\ \text { PLTD } & \text { Diesel Power Plant } \\ \text { PLTG } & \text { Gas Power Plant } \\ \text { PLTU } & \text { Electric steam power plant } \\ \text { PP } & \text { Government Regulations } \\ \text { PPA } & \text { Power Purchasing Agreement } \\ \text { TPA } & \text { Final Dumping Site } \\ \text { RDF } & \text { Refuse-Derived Fuel } \\ \text { RUPTL } & \text { Electricity Supply Business Plan } \\ \text { TWh } & \text { TeraWatt hour } \\ \text { UU } & \text { Law } \\ & \end{array}$

\section{REFERENCES}

[1] https://www.kemendagri.go.id/ (accessed 1 november 2019)

[2] BPS. 2015. Luas Lahan Sawah Menurut Provinsi 2003-2015. Badan Pusat Statistik Bidang Energi

[3] BPS. 2017. Luas Kawasan Hutan dan Kawasan Konservasi Perairan Indonesia Menurut Provinsi Berdasarkan SK Menteri Kehutanan. Badan Pusat Statistik Bidang Energi

[4] BPS. 2019. Kapasitas Terpasang (MW) Perusahaan Listrik Negara (PLN) menurut Jenis Pembangkit Listrik, 1995-2017. Badan Pusat Statistik Bidang Energi

[5] ESDM. 2015. Pedoman Energi Terbarukan tentang PengembanganProyek Tenaga Listrik Biomassadan Biogas di Indonesia. E-Guidebook versi Bahasa Indonesia Edisi kedua, Februari 2015

[6] RUEN. 2017. Peraturan Presiden Republik Indonesia Nomor 22 Tahun 2017 Tentang Rencana Umum Energi Nasional.

[7] Vijai K.Gupta, Ravichandra Potumarthi, Anthonia O'Donovan, Christian P. Kubicek, Gauri Dutt Sharma, Maria G. Tuohy, Bioenergy Research: An Overview on Technological Developments and Bioresources, 2014, Pages 23-47

[8] Shusheng Pang, Fuel flexible gas production: Biomass, coal and biosolid wastes, 2016, Woodhead Publishing, Pages 241-269

[9] http:// www. Iea .org /stats /defs /sources /renew.asp (accessed 10 September 2019)

[10] http://www.euromonitor.com (accessed 10 September 2019)

[11] Vladimir Strezov. 2014. Biomass Processing Technologies. Taylor \& Francis Group, LLC. ISBN : 978-1-4665-6616-3

[12] Petir Papilo, Kunaifi, Erliza Hambali, Nurmiati, Rizfi Fariz Pari, Penilaian Potensi Biomassa Sebagai Alternatif Energi Kelistrikan, Jurnal PASTI, 2015, Volume IX No 2, 164-176

[13] Arief Tajalli, Panduan Penilaian Potensi Biomassa Sebagai Sumber Energi Alternatif di Indonesia, Penabulu Alliance, 2015.

[14] Harwin Saptoadi, Moch. Syamsiro, Bisrul Hapis Tambunan, Pemanfaatan Limbah Biomassa Cangkang Kakao dan Kemiri
Sebagai Bahan Bakar Briket, Jurnal Manusia Dan Lingkungan Vol 14 No 32007

[15] https://drive.esdm.go.id// (accessed 1 november 2019) 